DOI: 10.20472/IAC.2017.33.013

\author{
JIM FISCHER \\ Mount Royal University, Canada
}

\title{
IS CONSUMPTION TAX REGRESSIVE? A LIBERTARIAN PERSPECTIVE
}

\begin{abstract}
:
Libertarians see a minimalist role for the state at best. That role should be limited to protecting liberty, or the ability of individuals to pursue economic opportunity. In doing so, the state provides the means for individuals to resolve contract disputes that inevitably result when one individual's claim or pursuits conflict with another. To fulfill this role of administering justice, the state needs a revenue source. Traditionally, liberal democracies have allowed income tax to evolve as the prime source of revenue. This is difficult for libertarians, who see income tax as the theft of individual property by the state. Consumption tax is another option for financing the state, but it has been criticized as being regressive, and therefore unfair in its application. This paper challenges that assumption and makes the case that consumption tax, when applied as a retail sales tax at the point of sale, has inherent characteristics that make it progressive. As such, it overcomes the criticisms that libertarians find with income tax and make it a more acceptable alternative revenue source for financing the limited role of the state.
\end{abstract}

\section{Keywords:}

consumption tax, income tax, libertarian, progressive tax, regressive tax

JEL Classification: E21, H21 


\section{Introduction}

Constitutions in liberal democracies entrench democratic rights. They also stipulate ways for the state to raise revenue, including income tax. Income tax is viewed by libertarians as theft and therefore anathema to a liberal society (Rothbard, 2006). Despite this, minimalist state libertarians see a need to finance the state so it can undertake its singular role, the administration of justice to ensure liberty. Liberty and democracy are both complementary and antagonistic to each other. Freedoms associated with democracy must be present if a free market dependent on the exchange of information can thrive (Hayek, 1960). However, the democratic premise of majority rule assists in eroding the economic freedom of the individual when it allows the state to take on a redistributive role (p. 116). Previous studies (Jasay, 1998) expose income tax, not democracy, as the culprit in the erosion of liberty that occurs when the state takes on the role of redistributing wealth. The problem for the libertarian is how to limit the state to its basic role and still provide a revenue source that is not based on income tax. Consumption tax has been examined as an alternative that can provide the minimalist state its revenue, and still provide for liberty (Fischer, 2015). While consumption tax may meet libertarian criteria for replacing income tax and financing the minimalist state, it does face some criticism. Most notably, it is frequently claimed that consumption tax is regressive. This paper dispels this myth. When consumption tax replaces income tax as the sole source of revenue for the minimalist state, it is inherently progressive.

\section{The problem}

This study approaches the problem of taxation with a view of economics consistent with what Mises (1963) referred to as praxeology. This view considers economics as a science of means rather than ends (p. 15). Taxation is a tool for providing the minimalist state the limited funds it needs to undertake its role of protecting liberty. It does not see economics as a tool for engineering the economy and thus rejects the scientism of Keynesian economics. A libertarian consideration of tax regards it as the means for creating an environment more akin to the classical liberal view of liberty and freedom, where people are free to make decisions affecting the procurement and enjoyment of their property. Decisions are made based on available and relevant information and experience as opposed to being engineered by a mathematical plan that ignores experience and personal preferences.

Libertarian scholars and their cousins in the Austrian school of economics have not been detailed in their prescription of how the minimalist state should be taxed. Hayek contributed much to the defense of liberty and, to a lesser extent, democracy, but less in addressing the problem of taxation. A chapter of The Constitution of Liberty (Hayek, $1960)$ does provide a detailed reflection on progressive income tax. He wrote specifically 
about how progressive taxation robs from the successful (Nishiyama \& Leube, 1984). Progressive income tax is a disincentive for those who would make use of their resources to further themselves in a free society. He did not venture into what would be a better form of taxation. He hinted at the possibility that inheritance tax could make for a better distribution of wealth, but acknowledged it is also a form of robbing the successful and has been abused by governments (p. 118). Unfortunately, other taxation means were not further developed by Hayek.

Before any tax is collected, the question must be asked: what is its purpose (Sundberg, 1993, p. 233)? If the purpose goes beyond financing the state's minimalist role of protecting individuals and their property from coercion, then taxation is transformed from a means of financing the state's minimalist function to a means of allowing the state to carry out its own agenda (p. 234). Increasing taxes to provide for a higher degree of social justice is based on fallacious reasoning. If higher tax rates make for a greater transfer of wealth of services, then there is a built-in assumption that a tax rate of $100 \%$ provides for the maximum level of services and justice possible (p. 238).

If income tax is anathema to libertarian thinking, then an alternative must be found. Consumption tax is proposed as the replacement that would meet libertarian criteria. Previous studies have made a case for consumption tax as a replacement for income tax that is amenable to the libertarian need for personal enjoyment of property (Fischer, 2015). A Canadian case study demonstrates that it is possible to replace income tax with consumption tax, maintain or increase the total revenue-generating potential of the state, and increase the spending power of individuals over time (Fischer, 2016). However, consumption tax has been widely criticized for being regressive. It is necessary to defuse this claim in the modern mixed-economy state. If the state is expected to redistribute wealth, it must first be taken from those that have it. Progressive tax methods do this. Regressive tax methods tend to disproportionately take from those with less. Despite the efficiencies that it may promise, legislators may be reluctant to endorse consumption tax over income tax because of the regressivity claim.

\section{Definitions}

The consumption tax proposed is a retail sales tax (RST) imposed at the point of sale in transactions for goods and services. Previous Canadian case studies (Fischer, 2016) found that a RST of $29.73 \%$ applied at the point of sale on all goods and services could replace current income and consumption tax regimes and still provide the government with its current levels of revenue. This figure will be used here as a basis for discussion.

There are numerous versions of consumption tax, such as the cash flow personal consumption tax and the Unlimited Savings Allowance (USA) Tax that was proposed by U.S. legislators in 1995 (Garrison, 1997), but they often share characteristics with income 
tax that make them unappealing for libertarians. These versions of a consumption tax still required individuals to report income annually. They also required financial institutions to report deposits and withdrawals of individuals so that consumption could be calculated (Garrison, 1997, p. 758). A RST collected at the point of sale does not require individual reporting.

Goldberg (2003) noted that a hybrid system of taxes has evolved in the United States and other Western democracies. He noted that instruments such as Registered Retirement Savings Plans (RRSPs) and Registered Education Savings Plans (RESPs) in Canada provide a measure of income tax freedom on savings and investment that consumption tax schemes usually offer, while not doing away with the income tax system. In the event that a greater degree of hybrid taxation is desired, Goldberg suggested it is expedient to consider treating corporations and individuals differently or treating different income classes of individuals differently. For example, he suggested that income tax might only be imposed on very high earners, but everyone would be subject to a flat sales tax. Such a tax structure would hardly pass the scrutiny of a libertarian perspective given its retention of income tax.

Libertarianism exists in degrees. In its extreme form, there is no role for the state. In its less extreme form, a minimalist state is acceptable to maintain an environment where liberty may thrive. This is the form used in this paper. Minimalist state libertarianism recognizes that a state is necessary to provide for the protection of individual liberty through the administration of justice. This role, carried out through the enforcement of contracts, is the only role of the minimalist state. To provide for the minimalist state, a revenue source is required.

\section{Previous studies}

Using the American excise tax on gasoline as an example, Chernick and Reschovsky (2000) came to the conclusion that gasoline taxes are regressive for those in the bottom half of the of the income distribution. Choosing a lifetime model rather than an annual model, they recognized that their study faced other difficulties, such as considering the mobility of the members of the sample over their lifetime. They stated that the lowest half of the income distributions face eleven-year gasoline tax burdens that consumed on average $0.86 \%$ more of their income than those in the upper half of income distributions. While this can create economic hardship for the lowest income earners, they still believed it to be less punitive than other forms of taxes. They also recognized that there were ways to remedy the regressivity of this and suggested it was the role of government to ensure measures were put in place to do so, without expanding on what those measures might be. 
Creedy (1998) provided a different view by noting that it is more preferable to consider the overall impact of all taxes and transfer payments than relating payments of a single tax to gross income. Also, if consumption tax is considered in isolation, it is best measured in terms of household total expenditure, rather than gross income (p. 107). With this statement, Creedy broke with traditional economic analyses that focus on income and shifted to consumption or expenditure. This recognized that consumers do not have to spend all their earnings in a consumption tax regime but have a choice between spending and saving.

The regressivity argument in the Canadian context was approached by Gillis (1986). He drew from the experience of jurisdictions which had been using consumption taxes prior to 1986 to illustrate pitfalls to those which were contemplating it at that time. Canada then was contemplating a federal Goods and Services Tax (GST) to replace an outdated Manufacturer's Sales Tax. This was in addition to any Provincial Sales Tax (PST). Gillis concluded that the regressivity argument against consumption taxes could easily be countered by means other than making consumption tax rates progressive. He cautioned states contemplating the imposition of a consumption tax against using it for redistributive goals, as it would counteract the economic and administrative gains that a uniform rate would encourage. These cautions expressed by Gillis demonstrate an understanding of the merits of a consumption tax in promoting efficiencies and prosperity, while recognizing their potential misuse as a means of redistribution of wealth.

The regressivity claim by detractors of consumption tax is further refuted in a later Canadian case study. Researching in Quebec, Godbout and St-Cerny (2011) disproved the belief that the province's consumption tax was regressive, despite popular opinion to the contrary. Using data from Statistics Canada's 2008 Survey of Household Spending, they examined taxable and non-taxable spending among five quintiles of household incomes. Because of the exclusion of certain goods and services from GST/PST, and refundable credits, the share of GST/PST paid by the lowest $20 \%$ income bracket was $2.6 \%$, whereas the share paid by the highest income bracket was $44.1 \%$. This demonstrated that consumption tax, particularly in the form of a RST, brings in larger sums from the wealthy not so much by design as by default. They pay more tax because they purchase more. This will form a core argument of the libertarian defense of consumption tax, as it suggests those who acquire the most property pay the proportionate amount for the protection of that property.

Hall (1997) also considered the effect of a consumption tax on housing, a significant expense for most individuals and therefore a large source of government revenue if taxed. Housing in Canada is already treated on a consumption tax basis to some degree. Sales of prime residences are not subject to capital gains tax, a form of income tax. Sales of new homes carry a sales tax. A switch to a consumption tax regime would not affect this aspect of home sales. However, home purchases would be one of a number of 
investment choices that consumption tax makes more attractive, given the increase in purchasing power the consumer has in a purely consumption tax regime.

Heer and Trede (2003) ran two models to examine the repercussions of the imposition of either a flat tax or consumption tax regime in Germany, inspired by the discussions over such tax reform possibilities in 1996. In each case the new tax system would replace an income tax system. They concluded that both efficiency and welfare improved with either reform, compared to the progressive income tax system in place at the time. Employment rose by $2 \%$ in each of the new regimes. Savings increased by $15 \%$ and $35 \%$ respectively in the flat tax and consumption tax models (pp. 102-103).

In summary, the regressivity of consumption taxes was challenged by numerous scholars. Those that challenged the regressivity claim applauded consumption taxes for their contribution to long-term productivity (Milesi-Ferretti \& Roubini, 1998); their contribution to GDP relative to income taxes, a measure of economic efficiency (Clemens \& Veldhuis, 2008); and their increased administrative efficiency (Blagrave, 2005). Those that did disclose some regressivity did not regard it as important. Chernick et al. (2000) regarded it as only a minor problem, but still viewed consumption tax to be more advantageous to society than income tax. Creedy (1998) and Godbout et al. (2011) both thought any tendency to regressivity could be countered, giving consumption tax the benefit of the doubt over income tax in its ability to benefit the economy. The research acknowledges manageable challenges to consumption tax, supports its ability to promote productivity, and contradicts regressivity claims. Many of the authors noted that while consumption taxes can be regressive, it is up to those implementing them to ensure they are not.

\section{Consumption tax as a progressive alternative to income tax}

In proposing consumption tax as an alternative for financing the minimalist state, it is necessary to ensure that it not only eliminates the inadequacies of income tax, but that it still meets libertarian criteria. Tests that should be met include:

1. taxes must be fair;

2. property must not be taken against individual will;

3. the rule of law must apply, specifically stipulating equality of individuals before the law.

Test 1: Taxes must be fair.

Libertarians may choose not to concern themselves with the regressivity issue specifically, but they do need to concern themselves with a fairness issue. An ideal tax 
regime should not discriminate against anyone and should not take from anyone the essential means required to sustain life.

A RST has inherent features of progressivity. A greater proportion of taxes will in fact be paid by wealthier individuals because they will likely be consume larger items and do so so more frequently. The choice to consume is one they make, not one that the state imposes on them. Even if the rate of taxation on purchases is the same for all, those who accumulate assets will pay a higher percentage of the costs associated with those assets. Police and judicial services provided by the state will be financed proportionately by all individuals relative to the amount of property they acquire and therefore wish to protect. The rule of law ensures all will be treated fairly in property disputes. Those who have more property will not be treated any differently but, because they have more property, are more likely to need recourse to the administration of justice.

Arguments suggesting consumption tax is inherently regressive generally assume that all income earners would be paying it. In many Western democracies, including Canada, many low-income earners currently pay no income tax. A universally applied consumption tax would burden those who are currently paying no taxes, and would indeed be regressive. The $29.73 \%$ RST rate that this paper applies to the Canadian situation would be regressive if applied to all consumers, as it would impose a new $29.73 \%$ tax on low income earners who pay no or little income tax and may qualify for GST rebates. There are two ways of approaching this reality. One is to calculate a rate that is not applied to necessities. Determining what that list of goods and services might be is beyond the scope of this paper. If fewer people pay consumption taxes, the state must raise the $29.73 \%$ rate to provide the same services. A second way to approach this is to reduce government services to the basic provision of the administration of justice. By doing so, the $29.73 \%$ rate can be reduced. A lower rate and a list of exempted goods and services is needed. The compilation of such lists and an estimate of the cost of administering justice create normative debates that, again, are beyond the limits of this paper. Such debates provide much potential for further research.

Test 2: Property must not be taken against individual will.

The enduring question for minimalist state libertarians is how to finance the minimalist government. To concede that income tax should be tolerated only to allow the funding of the administration of justice in protecting liberty is a dangerous concession to make. It violates libertarianism at the core, in that it takes the property of individuals against their will. Ayn Rand suggested a contract fee instead of taxation (Long, 2008). The concept has value from the libertarian perspective in that it provides a measure of individual choice. It is unclear, however, what the repercussions would be for those that do not choose to engage in the contract fee. The RST offers another way of looking at the 
contract fee and resolves some of these uncertainties that surround it. When a RST is in place, only those entering into contracts are paying the fee and therefore protecting themselves against arbitrary resolution dispute. Sales are considered contracts. Those consuming the most are paying proportionately, thus the element of fairness is present. While all citizens pay the RST when they trade, how much they choose to trade beyond the need to provide for their basic necessities is an individual choice. The contract fee, as represented by the RST, is a set percentage of any prices paid. As such, it provides a fee proportionate to the size of the contract being negotiated. It is imposed only at the moment of decision making, not when the individual receives their income and has made no decision on how to dispose of it. Beyond the initial decision to impose such a fee by the state to fund its minimalist activities, the actual paying of the RST resembles Rand's contract fee, paid only when a contract is initiated and always at the same rate for all individuals.

Test 3: The rule of law must apply, specifically stipulating equality of individuals before the law.

The universally applied RST also meets the test of taxation proposed by Hobbes (1651), who suggested taxation should be done equally among all individuals, since all are receiving the same benefits of protection (p. 177). Equal in this sense suggests a proportionate payment, based on amount of consumption that is subject to one rate paid by all. Hobbes recognized the liberal concept of mankind wishing to consume to maximize individual pleasure and the role of the state as one that would make this possible. Universally applied RST is an equitable tax treatment in that all are paying the same percentage, in amounts relative to the property or services they are contracting for.

Numerous libertarian thinkers advocate transferring services currently provided by government to a market economy. In its extreme form, this includes the services that protect liberty. This may evoke concerns that the rich would have more votes than the poor, by virtue of the amount of goods and services they consume (Rothbard, 2006). Such arguments forget that apart from the right to enjoy property, a fundamental right involves equality before the law. This is not lost when a minimalist government raises revenue through a RST. Each party in the transaction pays the required fee to subsidize the mechanisms that resolve contract disputes. Wealthier citizens pay more fees through the RST over time because they enter into more and/or larger contracts for goods and services. However, in each individual contract entered, both parties have the same recourse for a resolution of any dispute that might arise over the terms of the sale. With equality before the law on a case-by-case basis, the rich enjoy no particular privilege over the poor. 


\section{Arguments against consumption tax}

By not taxing income, one has a greater opportunity to save. If a consumption tax regime encourages saving, there is a perception that only those who can afford to save do so. By not taxing the investment returns of those who can afford to save, the argument suggests that the absence of income tax on savings is regressive (Mintz, 2001, p. 82).

What this argument fails to recognize is that savings defer consumption. They do not eliminate it. It has been demonstrated that imposing a consumption tax in the form of a RST on spending from future earnings actually has the potential to raise equivalent taxes over time (Fischer, 2016). Deferred consumption through savings does not imply that the savings will never be spent. Instead, they are likely to generate a greater amount of purchases in the future that will be subject at that time to RST.

Most arguments against consumption tax consider the amount of consumption tax paid as a percentage of total income. An alternate view is to consider the amount paid as a percentage of total household expenditure (Creedy, 1998, p. 107). When measures are taken to alleviate the burden on lower income brackets, this becomes a more meaningful measurement.

Curatola et al. (2000) offered three remedies for the regressivity issue:

1. Provide exemptions for low income households, similar to a no-tax policy for businesses and non-profit organizations;

2. Do not tax necessities such as food and medicine. Other exclusions which can be added to the list include shelter, prescription drugs, certain transportation services, health and education services, child-care services, diapers, and books (Godbout \& St-Cerny, 2011, p. 471).

Wieler (1998) noted that $25 \%$ of American household budgets are spent on food. Therefore, exempting food purchases from sales tax would drive the sales tax rate on other items much higher, to a point which she suggested would be untenable (p. 72). Curotola et al. also noted that such exemptions may not lessen the regressivity burden since the state is likely to impose a higher tax on other items to make up for lost revenue (Curatola, Price, \& Weld, 2000, p. 18). Doing so, however, would mean a higher tax on items which the poor were less likely to buy, thus shifting the tax burden to those who could afford items beyond essentials. This shift of the tax burden to those who can afford it would be considered progressive.

3. Increase transfers from the government to negatively affected households.

Canada has a long track record of allowing tax credits to address impositions on the poor (Gillis, 1986, p. 128). This redistributive undertaking, while attempting to alleviate taxation on the less wealthy, still perpetuates the income tax system and the problems libertarians 
have with it. Government departments that determine who gets what are less efficient and more intrusive in individual lives than the solution of exempting certain basic and necessary goods. As stated earlier, further study can determine the services that the minimalist state should provide and what they will cost. This, combined with a list of goods and services which are exempt from the tax, should provide an RST rate that provides government with its revenue needs. It is not an additional burden for those who currently pay tax and does not impose a new tax on those who are currently exempt.

\section{Conclusion}

This paper argues that a universally applied RST is progressive by default because the amount of tax paid is proportionate to the consumption undertaken. Those with more wealth will consume more, particularly of expensive items. While a universal tax can be seen to be regressive given that the same tax applied to basic needs such as food is harder to bear for the least wealthy, there are remedies for this (Curatola, Price, \& Weld, 2000). Most notable is the ability to exempt some items such as food, clothing, and medicine from the tax. If the state wished to maintain current revenue levels after exempting basic items from a new consumption tax, other non-essential items will be taxed at a higher rate than the $29.73 \%$ proposed here. The items being taxed will be purchased by those with more disposable income available. The rate will be kept low by reducing government services, more in keeping with a libertarian perspective. As stated earlier, the determination of what services should be provided or what goods and services should be exempt are subjects beyond the scope of this paper.

The progressive nature of imposing higher taxation on the wealthy is not lost in the new consumption tax regime. Those who acquire more goods pay more tax. They also have a greater need for protective services and resolution of property disputes, since they own more property. This progressive feature is not the intent of the RST, but it happens by default. A libertarian argument is made drawing from Ayn Rand's concept of user fees. The new RST resembles a user fee in that those who require the mechanisms of the state for defending property will pay for it proportionately. At the same time, the services of the state for resolving contract disputes are made available to all equally by adhering to the primacy of the rule of law.

\section{Further study}

The penalty imposed on income earners by a new consumption tax who currently pay no or little income tax was addressed by a number of solutions, the most acceptable being to exempt basic necessities from the RST. This necessitates an increase in the consumption tax rate on non-exempt goods and services if government wished to 
maintain its revenues and provide its current level of services. What constitutes basic exemptions, and what the level of services the government will provide beyond its minimal role of administering justice, are normative debates that are natural extensions to the conclusions reached here.

\section{References}

Blagrave, P. (2005). An Analysis of the Impact of the Harmonized Sales Tax on Provincial Revenues in Atlantic Canada. Canadian Public Policy, XXXI(3), 319-331.

Buchanan, J. M. (2009). Economists Have No Clothes. (M. Baurmann, \& B. Lahno, Eds.) RMM, 0, 151-156. Chernick, H., \& Reschovsky, A. (2000). Yes! Consumption Taxes are Regressive. Challenge, 43(5), 60-86.

Clemens, J., \& Veldhuis, N. (2008). Not All Taxes Are Created Equal. In J. Clemens (Ed.), The Impact and Cost of Taxation in Canada: The Case for Flat Tax Reform (pp. 33-53). Vancouver: The Fraser Institute.

Creedy, J. (1998). Are consumption taxes regressive? Australian Economic Review, 31(2), 107-116.

Curatola, A. P., Price, C. E., \& Weld, A. G. (2000). National retail sales tax-a real choice? Strategic Finance, 82(3), 16-18.

Fischer, J. (2015). Consumption Tax, Liberty, and Democracy: Financing the Minimalist State. Papers and Proceedings 2015 International Conference of Prices and Markets. 5, pp. 5-10. Toronto: Ludwig von Mises Institute of Canada. Retrieved from http://pricesandmarkets.org/wpcontent/uploads/2016/12/JofPM-Issue-5-V.-1-ICPM-PP-2015-FINAL.pdf

Fischer, J. (2016). The Effects of Replacing Income Tax with Consumption Tax on the State and the Individual: A Canadian Example. Proceedings of the 24th international Academic Conference (pp. 122-130). Barcelona: International Institute of Social and Economic Sciences. doi:10.20472/IAC.2016.024.031

Forbes, S., \& Ames, E. (2009). How Capitalism Will Save Us: Why Free People and Free Markets are the Best Answer in Today's Economy. New York: Crown Publishing.

Garrison, R. W. (1997, December). Review of the book The USA Tax: A Progressive Consumption Tax, by Laurence S. Seidman. The Freeman, 47(12), 758-59.

Gillis, M. (1986). Worldwide experience in sales taxation: Lessons for North America. Policy Sciences, 19(2), 125-142.

Godbout, L., \& St-Cerny, S. (2011). Are consumption taxes regressive in Quebec? . Canadian Tax Journal, 59(3), 463-493.

Goldberg, D. S. (2003). The U.S. consumption tax: Evolution, not revolution. Tax lawyer, 57(1), 1-31. 
Hall, R. E. (1997). Potential disruption from the move to a consumption tax. American Economic Review, 87(2), 147.

Hayek, F. A. (1960). The Constitution of Liberty. Chicago: The University of Chicago Press.

Hazlitt, H. (1972). The Conquest of Poverty. New York: The Foundation for Economic Education.

Heer, B., \& Trede, M. (2003). Efficiency and distribution effects of a revenue-neutral income tax reform. Journal of Macroeconomics, 25(1), 87-107.

Hobbes, T. (1651). Leviathan. Oxford, Massachusetts: Project Gutenberg Literary Archive Foundation.

Jasay, A. d. (1998). The State. (Library of Economics and Liberty) Retrieved January 28, 2011, from http://www.econlib.org/library/LFBooks/Jasay/jsyStt14.html

Long, R. T. (2008). Market Anarchism as Constitutionalism. In T. R. Machan, \& R. T. Long (Eds.), Anarchism/Minarchism: Is a Government Part of a Free Country? Abingdon: Ashgate Publishing Group.

Milesi-Ferretti, G. M., \& Roubini, N. (1998, November). Growth Effects of Income and Consumption Taxes. Journal of Money, Credit, and Banking, 30(4), 721-744.

Mintz, J. M. (2001). Taxing Future Consumption. In P. Grady, \& A. Sharpe (Eds.), The State of Economics in Canada: Fetschrift in Honour of David Slater (pp. 79-94). Ottawa: Centre for Study of Living Standards.

Mises, L. v. (1963). Human Action: A Treatise on Economics. San Francisco: Fox and Wilkes.

Nishiyama, C., \& Leube, K. R. (Eds.). (1984). The Essence of Hayek. Standord: Hoover Institution Press, Stanford University.

Rothbard, M. N. (2006). For a New Liberty: The Libertarian Manifesto. Auburn: Ludwig von Mises Institute.

Sundberg, J. W. (1993). Revenue-only taxes vs. multipurpose taxes: Philosophy and implementation in Swedish high tax society. In G. Radnitzky, \& H. Bouillon (Eds.), Government: Servant or Master? (pp. 233-54). Amsterdam: Rodopi.

Wieler, S. (1998, November-December). Consumption Taxes: Do They Spur Growth? Challenge, 60-74. 